\title{
From cytometry to macroecology: a quarter century quest in microbial oceanography
}

\author{
William K. W. Li* \\ Ocean Research and Monitoring Section, Bedford Institute of Oceanography, PO Box 1006, Dartmouth, \\ Nova Scotia, Canada, B2Y 4A2
}

\begin{abstract}
A quarter of a century has passed since the contemporary ecological role of water column microbes was first articulated. It was also about a quarter of a century ago that 2 other seemingly unrelated developments first appeared: the application of flow cytometry for analysis of marine microbes and the statistical approach of macroecology for the analysis of complex ecological systems. These two developments now meet at the interface of microbial oceanography. The combination of these developments, termed cytometric macroecology, provides an avenue to explore general theories of ecology and biogeography, as well as a means to address environmental issues of long-term change. This case study examines the abundance of picoeukaryotic phytoplankton from weekly to multiyear time scales and from local to global space scales. Cytometric macroecology identifies patterns of regularity arising from flexible contingent circumstances, some of which-like anthropogenic disruptionsare of special interest because they appear outside the bounds of natural variability.
\end{abstract}

KEY WORDS: Bacteria · Cytometry · Ecological provinces · Macroecology • Picoeukaryotes · Phytoplankton $\cdot$ Prochlorococcus $\cdot$ Synechococcus

\section{INTRODUCTION}

The ecological role of water-column microbes in the sea was articulated by Azam et al. (1983) a quarter of a century ago, following earlier seminal ideas (Pomeroy 1974). Today, microbial ecology of the oceans (Kirchman 2008), or microbial oceanography (Karl \& Proctor 2007), is a scientific discipline that has branched tremendously from its roots. It was also about a quarter of a century ago that 2 other seemingly unrelated developments first appeared: the technological application of fluorescence-activated flow cytometry for individual cell analysis of aquatic plankton (Yentsch et al. 1983) and the embracive statistical approach of macroecology for inductive analysis of complex ecological systems (Brown 1984). These 2 developments now meet at the interface of marine microbial ecology, presenting oceanographers with a unique opportunity to explore general theories of ecology (Prosser et al. 2007) and biogeography (Martiny et al. 2006), as well as a means to address environmental issues at a global scale (Kerr et al. 2007). The combination of cytometry and macroecology enables the crossing of time and space scales from those of single cells to those of the global ocean.

Cytometry is 'a process in which physical and/or chemical characteristics of single cells, or by extension, of other biological or nonbiological particles in roughly the same size range, are measured' (Shapiro 2003, p. 1). Macroecology is 'a way of studying relationships between organisms and their environment that involves characterizing and explaining statistical patterns of abundance, distribution and diversity. Macroecology is concerned with the statistical distributions of variables among large numbers of comparable ecological particles' (Brown 1995, p. 18). Thus, macroecology requires many particles and cytometry can readily supply them. If there is an analogy between the statistical physics of collections of $10^{10}$ gas molecules and the ecology of assemblages of many individual organisms (Brown 1995), then the analogy has now drawn closer because that number of marine microbial cells 
has likely already been counted by cytometry in the totality of tens of thousands of sub-milliliter aliquots taken from global ocean surveys and multiyear monitoring programs over the past quarter century.

\section{HISTORICAL ROOTS}

The philosophical roots that unite cytometry and macroecology for marine microbes were already evident half a century ago, although not in terms of the neologisms. In 1956, Alfred Redfield addressed a symposium of experimental biologists who study life from the sea and declared, to a somewhat skeptical audience, that 'The most general problem of marine biology is to understand the distribution and abundance of life in the sea. The approach to this problem must be primarily statistical through the development of significant relationships between large quantities of observations on biological and physical events, occurring often in widely scattered places' (Redfield 1960, p. 22). Reflecting on the state of knowledge at that time, Redfield remarked that 'The first task of marine biology was to discover and describe what manner of plants and animals exist in the sea [...] New species may still be had for a dime a dozen, but it is rare that a new discovery alters our general conceptions greatly [...] The state of affairs is quite different so far as microorganisms are concerned. Marine bacteriology is only in its beginning, whereas the nanoplankton still resist investigation' (Redfield 1960, p. 22).

Marine flow cytometry sensu lato was first achieved in the form of Coulter counters (Parsons 1965). Particles flowing through a constricted aperture in an electrical field are detected by a size-dependent difference in resistivity between the particles and the seawater in which they are suspended, offering the possibility to construct size spectra for particulate matter in the sea (Sheldon \& Parsons 1967). Very soon thereafter, a Coulter counter was used on board the 'CSS Hudson' during its historic 1969-1970 voyage, believed to be the first circumnavigation of the continents of North and South America and returning to the ship's home port in Nova Scotia via the Northwest Passage of the Canadian Arctic seas (Edmonds 1973). The size distribution of particles, measured in both hemispheres of the Atlantic and Pacific Oceans (but evidently not in the Arctic Ocean), led to a hypothesis that, to a first approximation, roughly equal concentrations of material occur at all particle sizes from bacteria to whales (Sheldon et al. 1972). To some, the Sheldon hypothesis was 'exquisitely simple' (Edmonds 1973, p. 193). To others, it offered nothing more than 'the implied rediscovery of the Eltonian pyramid' (Platt 1985, p. 57). Whichever view is taken, the empirical biomass spec- trum of marine particles stands as the prototype of cytometric macroecology. Recent theoretical treatment provides a possible explanation for this cross-trophic spectrum from elementary principles (Brown et al. 2004).

In spite of its significant historical contribution, electrical resistivity particle counting no longer provides the information generally sought in contemporary microbial ecology. The reasons are fundamental: it does not discriminate cells from non-living particles, and it cannot easily discriminate signal from noise at bacterial sizes. On the other hand, fluorescence-activated multivariable analysis of cells that are hydrodynamically focused in a fluid stream (i.e. flow cytometry sensu strictu) has a shorter history in biological oceanography (Yentsch et al. 1983), but remarkable technical innovations have already delivered, and continue to promise, hitherto unavailable insights into microbial diversity and complexity. However, 'with all of its rigor, flow cytometry/cell sorting did little to overcome the problem of drastic undersampling of the oceans' (Yentsch \& Yentsch 2008, p. 108). Thus, the stage is set for an expansive approach.

In a separate historical trajectory, macroecology has branched from its roots in the division of food and space amongst terrestrial and avian species on continents (Brown \& Maurer 1989) to a much wider program of research (Smith et al. 2008), inclusive of marine communities (Witman \& Roy 2009). However, by whatever term we call this program of ecological research, the holistic description of macroscopic patterns in marine microbes, most especially phytoplankton (Li 2002), has a considerable history (Li 2007, 2009). With the promise of macroecology to make synthetic connections among different levels of organisation, there is now a common ground to examine the unity of ecology and evolution amongst diverse life forms, and microbes have become an integral part of this exploration.

\section{CYTOMETRIC MACROECOLOGY}

If it is not already clear, the prefix 'macro' refers not to the size of organisms, but to a scale of system organization higher than that of the interacting organisms. Thus, cytometric macroecology is concerned with statistical or emergent patterns arising from numerous ensembles of cells that have been measured or otherwise characterized, one at a time, on an individual basis. Microbial cells interact with their (abiotic and biotic) environment at spatial scales of nanometers to millimeters, and time scales of seconds to hours (Azam \& Malfatti 2007). However, the ecosystems in which microbes are embedded can be structured at scales of 
kilometers to megameters and years to decades. The combination of small-scale cytometry with large-scale macroecology is therefore a way to place marine microbes in the context of biogeochemistry, biogeography, climate change, macroevolution and other complex processes. The goal of such an ambitious synthetic endeavour might be consilience (Maurer 2000), but this does not preclude a more modest and urgent agenda to establish macroecological perspectives on the biotic consequences of global change (Kühn et al. 2008).

Global change is a rubric that encompasses a collection of environmental pressures (e.g. rising carbon dioxide, climate change, ocean acidification, ozone depletion, eutrophication, hypoxia, overfishing, biological invasion, xenobiotic dispersion) that do not necessarily share the same relevant scales of space and time. Therefore, finding a solution to mitigate these pressures will necessitate a match of scales between global change biology and macroecology, which is not evident in the current literature (Kerr et al. 2007). What is needed is an approach that allows macroscopic patterns to be formed from fine observations. The requirement for such an enterprise is local observations made at many ocean stations spaced kilometers to megameters apart and repeated over years to decades. In this review, a case study of picoeukaryotic phytoplankton is used to show that microbial oceanography is a fruitful area, not only for the application of existing macroecological concepts, but also for the development of new understanding in living systems.

\section{NECESSITY AND CHANCE}

The dialectic of necessity versus chance in biology (Monod 1971, de Duve 2007), or inevitability versus contingency, has ancient roots stretching to Plato (Mason 2006); however, it can also be reframed for ecology as a modern problem in deterministic chaos (May 1995). In a manner analogous to roulettes in casinos, biological processes at all levels of hierarchical organization (from genes to ecosystems) may be viewed as deterministic mechanisms functioning in chaotic domains that produce results appearing to have been generated by random processes (Pavé 2007). Thus, the lexicon of philosophy can be used, without burden of teleology, to conceptualize complex adaptive systems such as marine microbial communities. We may apply the following philosophical definitions to ecology: 'Necessity is the regular ground of possibility, expressed in scientific law. Chance is the means for the exploration and realization of inherent possibility, through continually changing (and therefore at any time contingent) individual circumstances'
(Polkinghorne 2005). In ecology, laws are widespread, repeatable patterns in nature that are underpinned by mechanisms contingent upon particular or stated circumstances (Lawton 1996). This is the essential condition for macroecology.

Inevitability and contingency in aquatic systems arise from environmental variability driven by different processes in a hierarchy of time scales (Reynolds 2002). The robustly predictable variables ('invariables') are day length and year length, arising from the rotation and orbit of the earth. The least predictable variables occur on very short time scales (e.g. waves, wind, clouds, precipitation, turbulence, and others) and at long time scales (e.g. climate change). In between, there are variables of estimable probabilities (e.g. daily and seasonal thermal stratification, carbon flux, nutrient loading, and many others).

The apparent regularity of phytoplankton seasonal development from year to year is a phenomenon that strongly shaped the early development of biological oceanography (Mills 1989), leading to contemporary typologies of phytoplankton cycles based on water stability, nutrient supply and illumination (Longhurst 1995). However, even patterns at this time scale, driven by the predictable annual orbit of the earth, are reshaped by local factors leading to a broad continuum rather than a narrow typology of seasonal patterns (Cloern \& Jassby 2008). This recent work shows that the month of maximum phytoplankton abundance at any particular location near the land-sea interface is what Reynolds might term a variable of low estimable probability.

\section{SCALES}

Averaging over longer time or spatial scales smoothes out variability at shorter scales. Nonetheless, smoothing is useful only with a dataset that is sufficiently extensive and fine-grained. In phytoplankton ecology, time series and spatial distributions of abundance based on microscope counts and chl a analysis have a longer history than those derived by flow cytometry. Thus, we can look briefly to the former for robust patterns.

One such example of multiscale time averaging is a study of phytoplankton in Bedford Basin at hourly intervals over the course of $1 \mathrm{yr}$ and at weekly intervals over decades (Li et al. 2008). The problem of predicting phytoplankton biomass (chl a concentration) from limiting nutrient (nitrate) concentration was made tractable by averaging at time scales that were short (hours, weeks) and long (decades), but not intermediate (years). Not surprisingly, Redfield stoichiometric conversion could account for the cases of predictive 
success. Remarkably, it held at both short and long time scales, implying uniform stoichiometric emergence from a range of processes with different time scales (cell physiology, population dynamics, community assembly, ecosystem development). Importantly, the stoichiometric conversion of $\mathrm{N}$ to $\mathrm{C}$ (proportional to chl a) is revealed as a consumption process at short time scales $(-\mathrm{N},+\mathrm{C})$, but as an accumulation process at long time scales $(+N,+C)$. Stoichiometric regularity at different levels of hierarchical organization may be a general feature of complex living systems (Sterner \& Elser 2002).

Paradoxically, prediction of biomass based on nutrient concentration fails at the annual time scale, which is precisely the scale at which the Redfield ratio for particulate $\mathrm{C}$ to particulate $\mathrm{N}$ in seston arises as an average value in this system (Li 2007). Variability of phytoplankton is perhaps most vexatious at the interannual time scale (Reynolds 2002) because the predictable orbit of the earth around the sun unpredictably resets microbial processes in the surface ocean to approximately (but not exactly) their starting conditions. In Bedford Basin, water temperature has a strong seasonal cycle, but yearly averages are not very different. On the other hand, salinity has a weak seasonal cycle, but yearly averages are substantially different. Thus, at the interannual scale, changes in density stratification are related to salinity, and so are changes in phytoplankton biomass (Li \& Harrison 2008). Phytoplankton are driven towards Redfield stoichiometry by springtime drawdown of nutrients and by an underlying, secular trend of eutrophication, but the actualized annual average concentration of phytoplankton is the result of stratification effects integrated over the whole year.

Generally, regularities (sensu Lawton 1996) can be evident at every scale, but the patterns need not be the same because processes become increasingly complex at higher levels of nested hierarchies. This will also become evident as we examine patterns of picoeukaryote abundance averaged over time and space in the following case study.

\section{TEMPORAL AVERAGING}

Time series observations are the essential element in discerning how natural microbial communities respond to global change. They are used to detect common patterns in the direction, magnitude and frequency of departures from long-term mean conditions in both environmental and ecosystem components. To link biological response with putative environmental drivers at the interannual scale, it is necessary to subsume intra-annual variations. In other words, the regu- larities of seasonality in the annual cycle must be removed to reveal year-to-year anomalies. An illustration of this is provided by a 16 yr time series of weekly flow cytometric measurements of autofluorescent (i.e. chl a bearing) picoeukaryotic cells in Bedford Basin. These microbes are taxonomically diverse unicellular algae defined by their small size (Vaulot et al. 2008). From an ecological point of view, they may be considered to comprise a functional group.

Data analysis and visualization essentially follows the protocol of O'Brien et al. (2008) for marine zooplankton time series. The first step is an inspection of the entire time series for data integrity and a quality check of logtransformed cell counts (Fig. 1A). The second step is computation of long-term norms (climatology) in the form of monthly means and standard deviations. For each year in the time series, weekly measurements are binned by month and averaged (filled dots, Fig. 1B). The grand average for each month taken across all years is the monthly norm (open circles, Fig. 1B). Each month-specific norm has an associated month-specific standard deviation drawn from the dispersion across years. The third step is to simultaneously visualize the monthly means at the intra-annual and interannual scales (Fig. 1C). The values for all monthly means in the time series $(\mathrm{n}=12 \times 16)$ are sorted numerically and divided into 20 equal-n member rank groups. The rankings are then each assigned a colour from the spectrum, with low monthly mean values assigned to short wavelength colours and vice versa. An alternative classification is the division of monthly means into equal-interval member rank groups, in which case some classes are likely to have only a very small number of members. The choice between these alternative classifications is largely one of cognitive preference.

The fourth step is the computation and visualization of monthly departures from normal conditions (Fig. 1D). The arithmetic difference between any of the $\mathrm{n}$ monthly means and the month-specific norm is the monthly anomaly. The monthly anomaly divided by the month-specific standard deviation yields the normalized monthly anomaly, which measures the deseasonalized departure from normal conditions in standard deviate units. Positive anomalies are coloured red and negative anomalies are coloured blue, with stronger hues assigned to stronger anomalies. Strong positive anomalies are defined as those greater than the mean of all positive anomaly values in the time series. Likewise, strong negative anomalies are those less than the mean of all negative anomaly values. The fifth, final step is the simple averaging of all 12 normalized monthly anomalies in each year to yield the normalized annual anomaly for that year.

The stepwise telescoping of weekly observations to normalized annual anomalies is a unidirectional pro- 

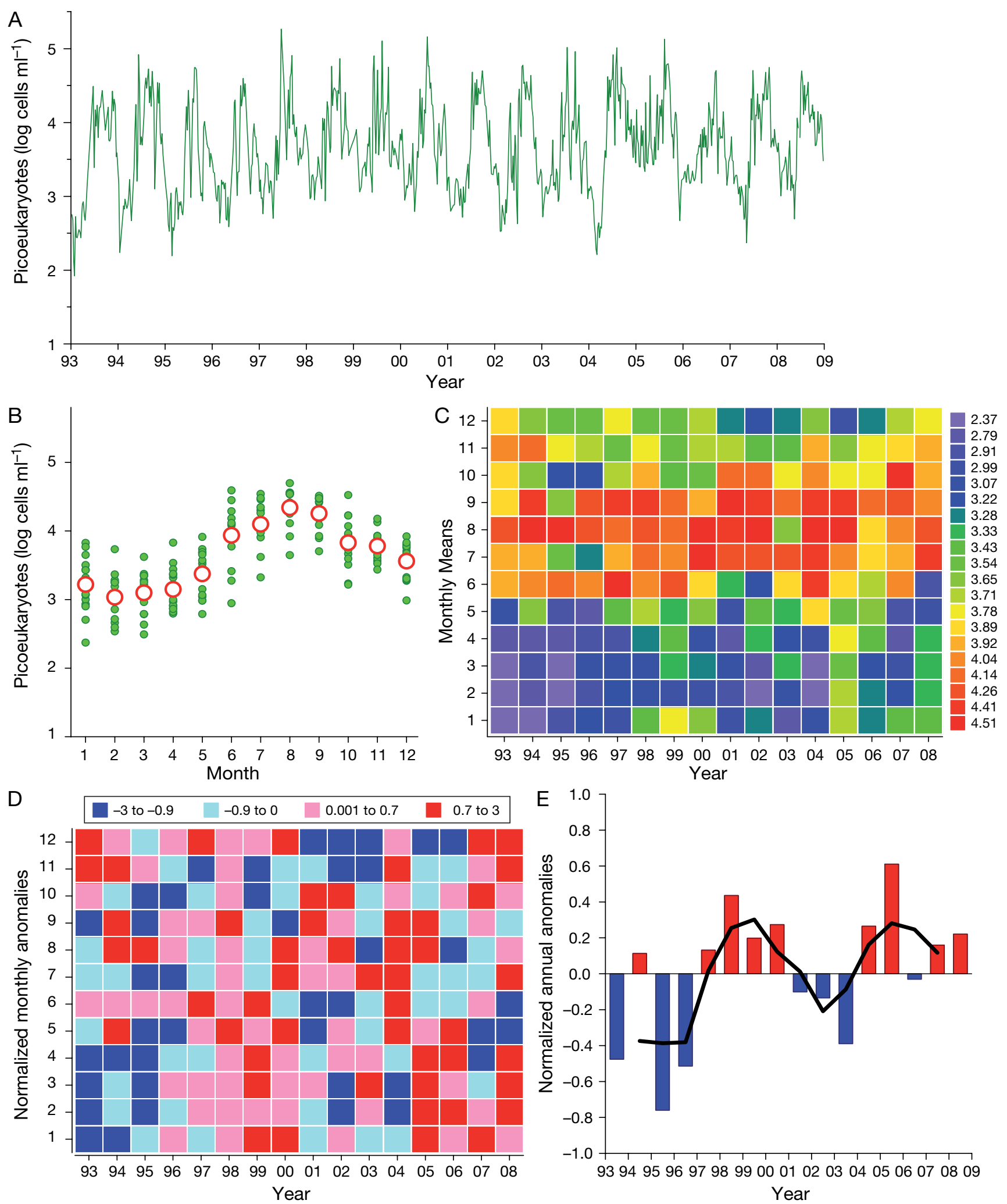

Fig. 1. Temporal averaging of picoeukaryote abundance in Bedford Basin. (A) Weekly time series. (B) Monthly means for each year (o) and monthly norms (O). (C) Monthly means in a time series of $12 \mathrm{mo} \mathrm{yr}^{-1}$ (rows) extending over $15 \mathrm{yr}$ (columns). (D) Normalized monthly anomalies in a time series of $12 \mathrm{mo} \mathrm{yr}^{-1}$ (rows) extending over $15 \mathrm{yr}$ (columns). (E) Normalized annual anomalies in successive years; solid curve is the 3-point running average. See 'Temporal averaging' for colour coding 
cess. At the annual time scale, the monthly and weekly features have been subsumed. Intuitive reduction is no longer necessarily reliable. For example, in 2006, there were $3 \mathrm{mo}$ of strong positive anomalies and 2 mo of strong negative anoamlies (Fig. 1D). However, the annual anomaly was slightly negative (Fig. 1E). Only by knowing that the August anomaly was so strongly negative can the net annual anomaly be understood. The plot of normalized annual anomaly for each successive year in the time series (Fig. 1E) is the starting point for testing hypotheses concerning long-term change. Since these anomalies are non-dimensional, they can be readily compared between variables, both biotic and abiotic, facilitating correlative linkages between external drivers and ecosystem responders, whether primary or secondary (Li \& Harrison 2008). In Bedford Basin, interannual change in picoeukaryote abundance is positively correlated with interannual change in nitrate concentrations (Cullen et al. 2007), suggestive of a long-term response to eutrophication.

The derivation of a coarse-grained macroscopic pattern (Fig. 1E) from fine-grained observations (Fig. 1A) is well suited to flow cytometric monitoring of marine microbes. At the microscopic end, observation time scales can be reduced by intense sampling using conventional methods (Jacquet et al. 2002) or new cytometric technologies that enable autonomous collection or analysis of microbes in continuous flow streams (Dubelaar \& Gerritzen 2000, Olson et al. 2003, Thyssen et al. 2008, Swalwell et al. 2009). At the macroscopic end, it is equally important to maintain a trajectory towards longer observation time scales by sustained monitoring of the ocean.

\section{SPATIAL AVERAGING}

Detecting signals of long-term change from spatially sparse observations is difficult. With the exception of visible spectral radiometry, which provides spatially continuous measures of phytoplankton pigments in the surface ocean by remote sensing, there is usually a mismatch of scale between physical (atmospheric and oceanographic) variables and microbial variables. Notwithstanding the promise of autonomous in situ microbial sensors (Paul et al. 2007), a network of ocean observing systems for microbes would only complement, but not replace, the 'boots on the ground' (Kerr et al. 2007) approach of collecting biological data. Conventional flow cytometry conducted on plankton collected at sea by discrete sampling has now created substantial databases suitable for preliminary analyses of multiyear microbial change at a regional scale.

Bedford Basin, or more precisely the Compass Buoy station, is a fixed location at the inshore end of a linear sampling transect extending from outside Halifax Harbour to the continental slope (Li et al. 2006). This transect (Halifax Line, HL; not including Bedford Basin), which crosses the central Scotian Shelf, lies downstream of a transect crossing the eastern Scotian Shelf (Louisbourg Line, LL) and upstream of another transect crossing the western Scotian Shelf (Browns Bank Line, BBL) (Fig. 2A). Integrated management of the Scotian Shelf, based on ecosystem and socioeconomic considerations, underlies the design of this monitoring network. Thus, although the pelagic seascape (hydrodynamics) and the benthic landscape (physiography) create spatial variability within the network, we seek time-dependent change at the level of the entire Scotian Shelf (or its eastern and western portions).

The method of discerning anomalies from normal conditions is extended, first to transects (station averaging) and then to the entire shelf (transect averaging). As the spatial scale is increased from a single location to a network of stations, practical considerations reduce the temporal resolution of the observations. In Bedford Basin (Fig. 1), our study is based on 1 station sampled weekly during each of the 12 mo over $16 \mathrm{yr}$ (effort $=1 \times 4 \times 12 \times 16$ ). On the Scotian Shelf (Fig. 2), our study is constructed from 21 stations that were sampled in 2 mo (April, October) over $11 \mathrm{yr}$ (effort = $21 \times 2 \times 11$ ). Moving offshore, the effort shifts from resolving time to resolving space.

For each transect, mean values from stations are computed for both April (spring) and October (autumn) for each year of the time series (Fig. 2B). For the shelf as a whole, means of transects are likewise computed for the 2 seasons (Fig. 2C). Shelf-wide averages of picoeukaryote abundance across all transects, adjusted from area to volume, are notably similar to local concentrations in Bedford Basin at any particular time when comparison is possible: low every spring and high every autumn (Fig. 2D). The within-year similarities are not surprising because, beyond a time scale of a few days, Bedford Basin and the adjoining continental shelf are physically coupled by the exchange of shelf and inshore water, largely caused by alongshore winds driving Ekman transport (Lewis \& Platt 1982).

Spatially extensive coherent seasonal development is evident for picoeukaryotes in this region (Fig. 2D). However, interannual change in picoeukaryote abundances over the continental shelf is more difficult to discern because the time series is short and because seasonality is inadequately resolved. Spatially averaged normalized anomalies (Fig. 2E) from both spring and autumn suggest that picoeukaryote abundances are increasing through time at a rate of $0.06 \pm 0.09 \mathrm{yr}^{-1}$ in spring and $0.07 \pm 0.11 \mathrm{yr}^{-1}$ in autumn. However, Kendall's non-parametric statistic $(\tau=0.16)$ indicates 
Fig. 2. Spatial averaging of picoeukaryote abundance on the Scotian Shelf. (A) Regional map of eastern Canada showing 3 sampling transects comprising 7 stations each. (B) Depth integrated abundance of picoeukaryotes at individual stations (filled symbols) and their mean (open symbols) measured in April (Spring) and October (Autumn) from 1997 to 2008 on the Browns Bank Line; trend lines are linear regressions of station averages. (C) Depth integrated abundance of picoeukaryotes as transect averages (filled symbols) and their shelf-wide mean (open symbols) measured in April (Spring) and October (Autumn) from 1997 to 2008 on the 3 Scotian Shelf transects; trend lines are linear regressions of shelf-wide means. (D) Depthaveraged shelf-wide mean abundance of picoeukaryotes (coloured symbols) in relation to weekly abundance in Bedford Basin (line, from Fig. 1A). (E) Normalized shelf-wide anomalies in spring and autumn; trend lines are linear regressions
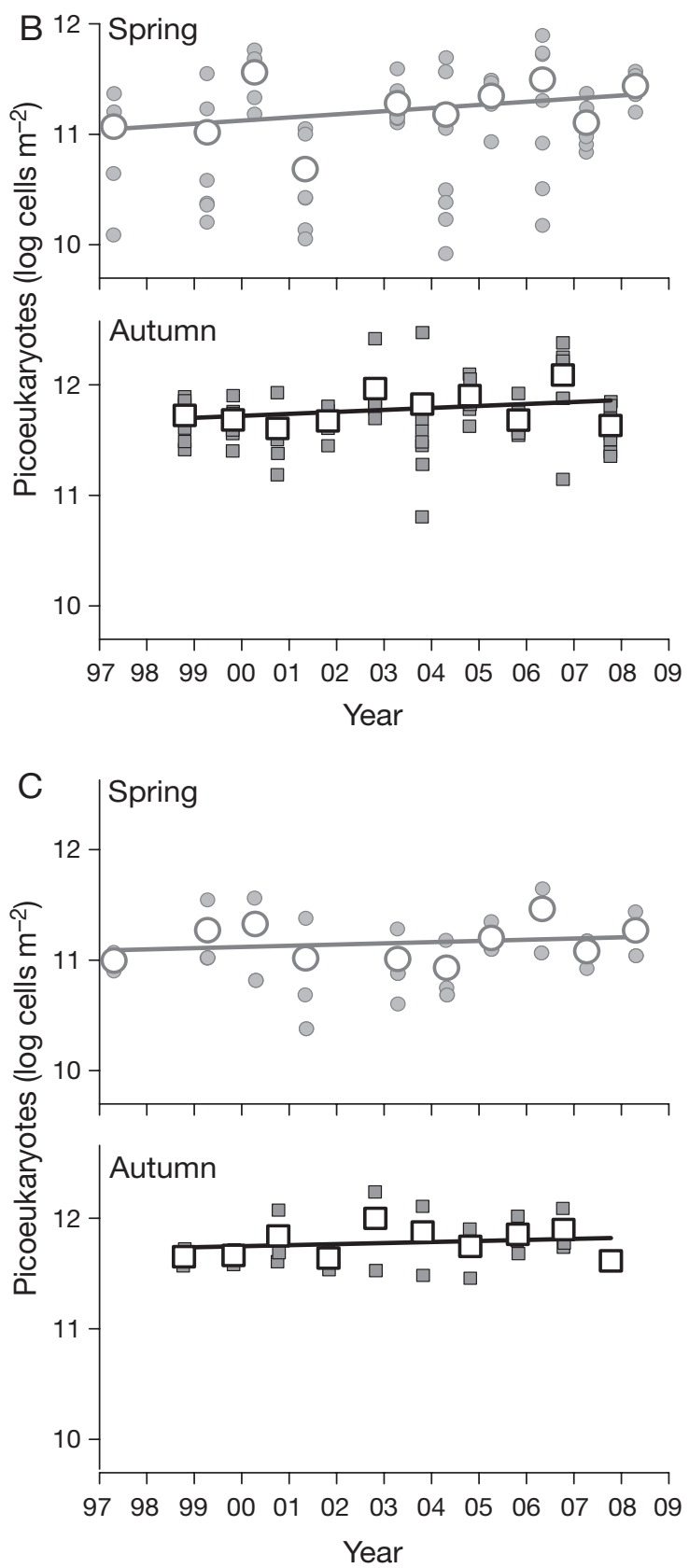
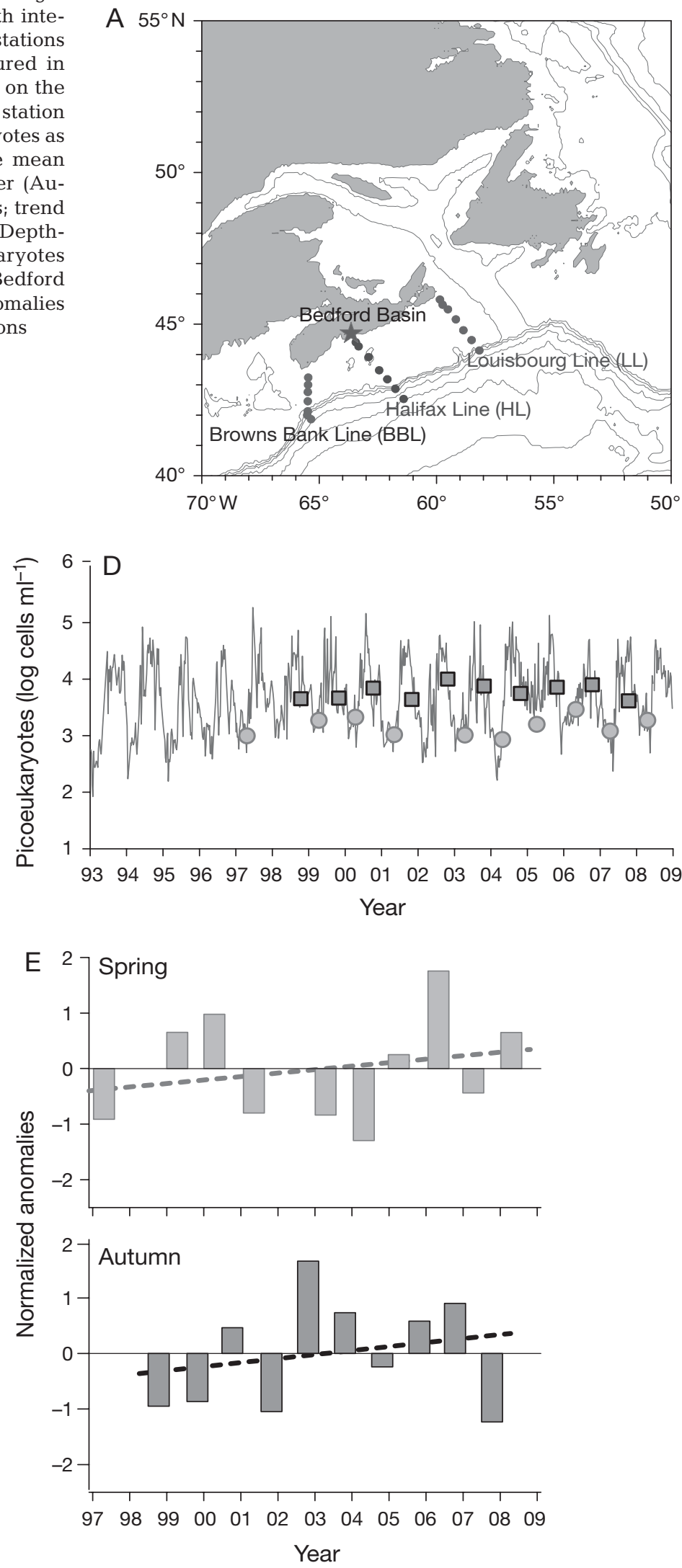
no significant rank correlation $(\mathrm{p}>0.10)$ between abundance and year in either season. Thus, a longterm increase in picoeukaryote abundance on the Scotian Shelf, if such exists, requires confirmation by a more robust trend.

At the intermediate spatial scale of continental shelves, which are larger than local embayments and smaller than ocean basins, the discrete sampling required to match relevant biological dynamics is most intense and often unachieved. Local features are idiosyncratic and global features are regular, but regional features depend heavily on context from both lower and higher levels. In particular, continually changing hydrodynamics on the Scotian Shelf greatly complicate the interpretation of multiyear spatial patterns of phytoplankton development. The effects of climateinduced ocean freshening in our study area are probably altered by other local and remote forcings, such as slope water intrusions (Ji et al. 2007). Complex ecosystems can extract weak signals spread across different driving variables (Taylor et al. 2002); however, there are often not enough direct observations over space and time to allow empirical demonstration.

\section{GLOBAL AVERAGING}

A global macroecology for marine microbes will serve to highlight the uniformity and the particularities of ecological, evolutionary and biogeographic laws in the living world. The contribution of cytometric macroecology to such a global perspective is already evident (Martiny et al. 2006, Smith et al. 2008) and is a motivation for pattern seeking at the largest scales.

Predictability at large scales is obtained at a cost of losing idiosyncratic details. Thus, we subsume the rich details of both Bedford Basin and the Scotian Shelf by embedding them within a more extensive regional large marine ecosystem (LME), which itself is embedded in an ecological province extending from the continental shelf of Florida to the Grand Banks of Newfoundland. This province, called the Northwest Atlantic Shelves Province (NWCS), is one in a global set of 51 non-overlapping regions that are formulated based on their physical and biological oceanography (Ecological provinces, Longhurst 2007). The basis of this global biogeography lies in regional diversity of the seasonal evolution of phytoplankton growth and in ecologically significant physical processes in the upper ocean. Each province is a high-level element in space (e.g. ocean basin) that, by virtue of hierarchical nesting, constrains variable local behaviour in lower-level elements (e.g. bays, banks, channels). Longhurst provinces therefore provide a rational organization for the emergence of macroscopic pattern.
Over a duration of 19 yr, we made 5814 flow cytometric measurements of picoeukaryote abundance at various depths in the upper $20 \mathrm{~m}$ of the ocean from more than 2000 hydrographic casts scattered across 24 provinces (Fig. 3A). Most locations in NWCS, Atlantic Arctic Province (ARCT), and Boreal Polar Province (BPLR), were repeatedly sampled (e.g. Fig. 2), but those elsewhere were mostly only sampled once. The binning of all data into separate province classes and the averaging over all times and places within each province allows us to seek macroscopic patterns. For this, province-wide averages of picoeukaryote abundance are displayed against average values of other variables (latitude, temperature, chlorophyll) binned in the same manner. Thus, latitude is averaged over discrete sampling locations, not across the full spatial extent of a province as defined by Longhurst (2007). Likewise, the average temperature and chlorophyll $a$ (chl a) concentrations indicated for a particular province are the values arising from discrete measurement at sampled locations; they are not climatological values obtained by gridding an ocean atlas over the entirety of a province.

On average, picoeukaryotes are most abundant at temperate mid-latitudes in both hemispheres and decrease both equatorward and poleward (Fig. 3B). A polynomial curve fit of the order 4 is required to delineate the bimodal distribution across latitudes. Due to the general symmetry of water temperature between both hemispheres, picoeukaryote abundance can be described by a polynomial curve fit of the order 2 to delineate the unimodal distribution across temperatures (Fig. 3C). Finally, the simplest description of average picoeukaryote abundance $(N)$ can be taken as a curve fit of the order 1 (straight line) with respect to average chl a concentration (Fig. 3D). The statistical relationship between log-transformed variables (Table 1) has a slope $<1$, indicating a greater relative importance of picoeukaryotes in provinces with low average phytoplankton biomass. This confirms for picoeukaryotes what is known for picocyanobacteria, namely that cell size is a dominant factor that shapes phytoplankton community structure.

In this preliminary exercise, we have not weighted the analysis to account for the highly uneven representation of data across provinces (ARCT, BPLR and NWCS account for $81 \%$ of the observations). Nevertheless, the global patterns with respect to latitude, temperature and chl a are striking. Elsewhere, we have confirmed the robustness of these patterns by Monte Carlo simulation through random selection of a large number of observations (W. K. W. Li unpubl. data).

The direct scaling of picoeukaryote abundance $(N)$ with chl $a$ is tremendously important. That is to say, there is a power law $\left(N=\mathrm{a}\right.$ chl $\left.a^{\mathrm{b}}\right)$ that allows predic- 


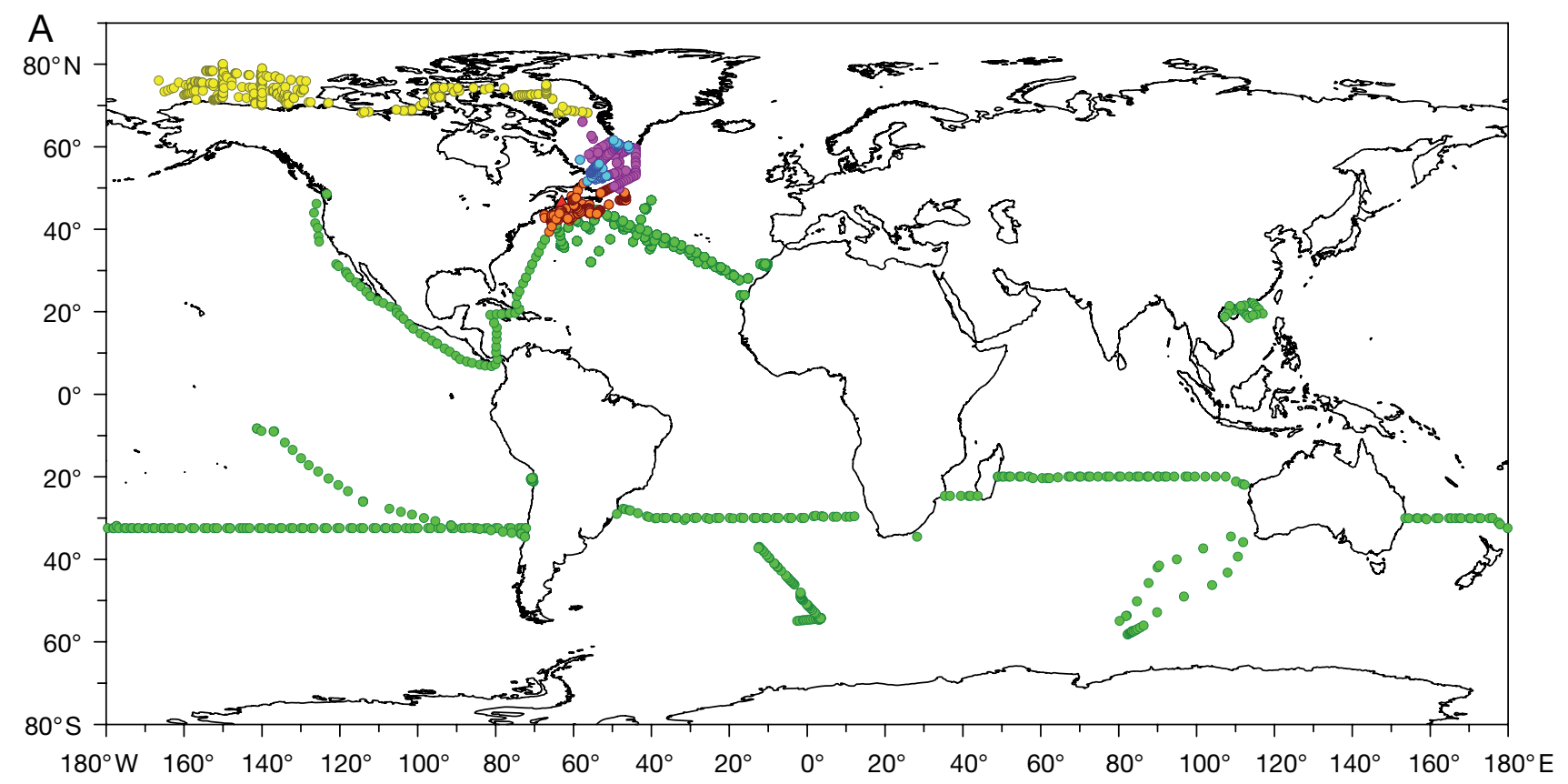

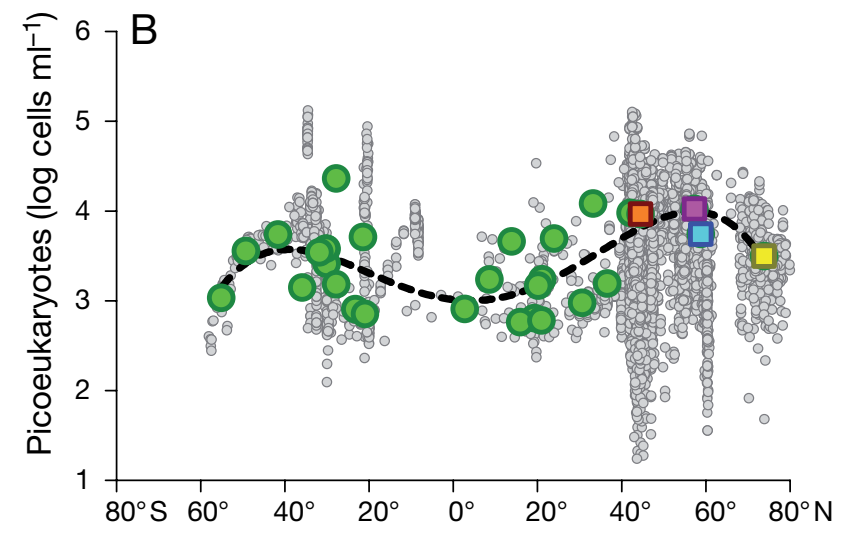

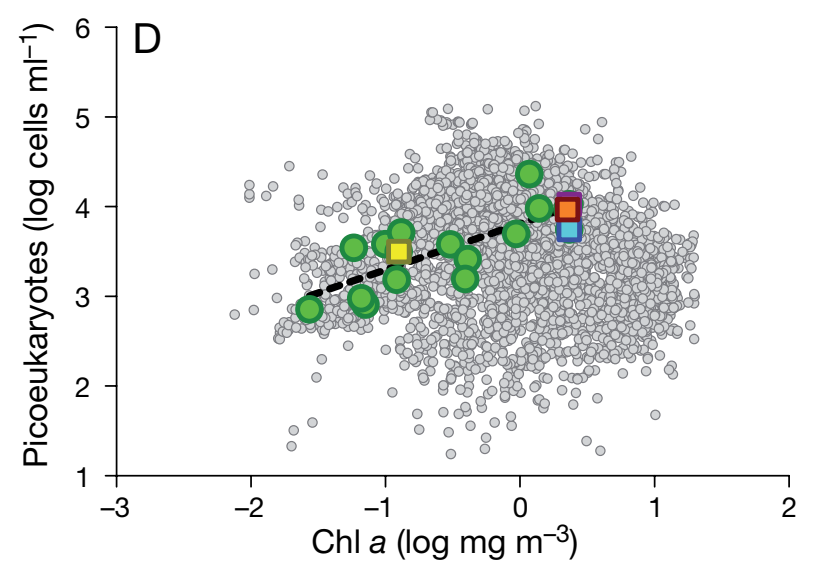

tion. Scaling places picoeukaryotes and other microbial functional groups (Fig. 4) in the context of global biogeography, global biogeochemistry and global change, where chl $a$ is a primary variable. The high degree of statistical confidence in all examined rela-

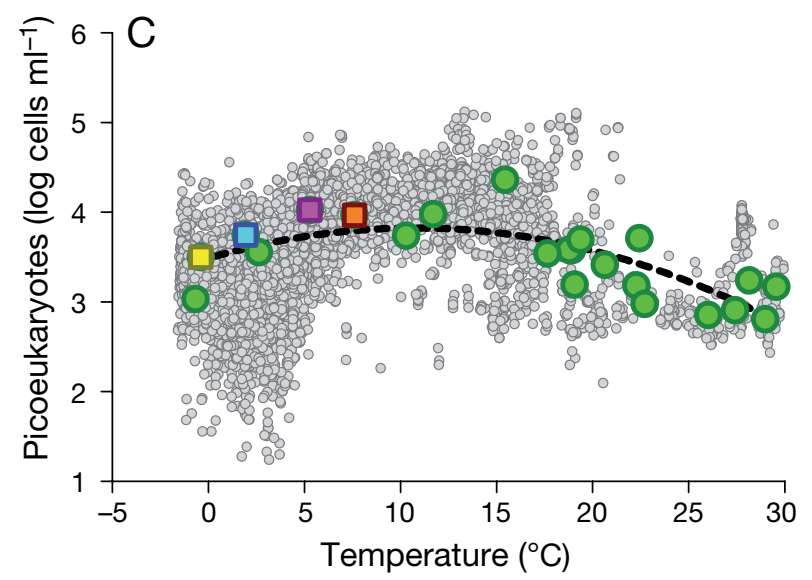

Fig. 3. Global averaging of picoeukaryote abundance binned into Longhurst ecological provinces. (A) Map of more than 2000 hydrographic casts, colour-coded by ecological province: Northwest Atlantic Shelves Province (orange), Atlantic Artic Province (pink), subarctic Boreal Polar Province (BPLR) (blue), arctic BPLR (yellow), others (green). (B) Latitudinal distribution of picoeukaryotes at individual sampling locations (grey) and as province-wide averages. (-----) 4 th order polynomial curve-fit of averages. (C) Temperature distribution of picoeukaryotes. (---_-) 2nd order polynomial curve-fit of averages. (D) Picoeukaryote abundance in relation to chlorophyll a (chl a) concentration. (-----) linear regression of averages. Colours in (B-D) correspond to (A)

tionships (Table 1) affirms a robust macroecological scaling of microbial abundance. Prochlorococcus differs from other microbes in at least 2 ways: it is known and confirmed to be absent from subpolar and polar waters, and its abundance scales negatively with chl a 
Table 1. Province-wide average microbial abundance $(N)$ in relation to chlorophyll a concentration (Chl) in the upper ocean, $z \leq 20 \mathrm{~m} . \log N=$ intercept + slope $\times \log \mathrm{Chl}$

\begin{tabular}{|c|c|c|c|c|c|c|}
\hline Microbial group & Intercept & SE intercept & Slope & SE slope & $\mathrm{r}^{2}$ & $\mathrm{p}$ \\
\hline Picoeukaryote phytoplankton & 3.81 & 0.09 & 0.51 & 0.11 & 0.61 & 0.00023 \\
\hline Synechococcus ${ }^{\mathrm{a}}$ & 4.58 & 0.11 & 0.65 & 0.13 & 0.66 & 0.00043 \\
\hline Prochlorococcus & 4.23 & 0.16 & -0.58 & 0.19 & 0.45 & 0.00867 \\
\hline Heterotrophic bacteria & 5.90 & 0.05 & 0.30 & 0.06 & 0.63 & 0.00013 \\
\hline Small nanophytoplankton & 3.04 & 0.08 & 0.44 & 0.09 & 0.62 & 0.00030 \\
\hline Large nanophytoplankton & 1.98 & 0.07 & 0.53 & 0.08 & 0.75 & 0.00003 \\
\hline
\end{tabular}
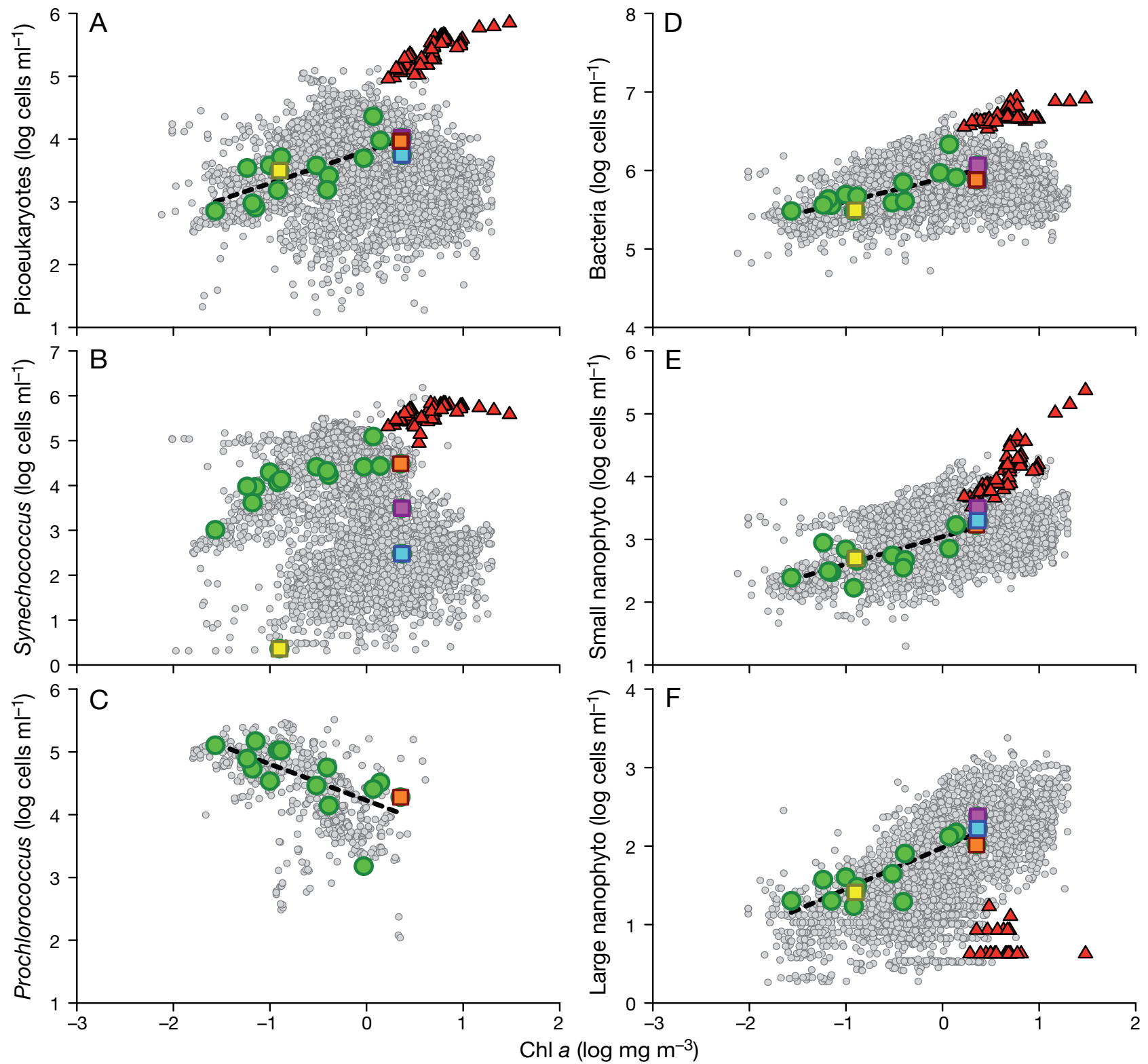

Fig. 4. Microbial abundance in relation to chlorophyll a (chl a) concentration in the upper ocean, $z \leq 20 \mathrm{~m}$. (A) Picoeukaryotic phytoplankton; (B) Synechococcus; (C) Prochlorococcus; (D) heterotrophic bacteria; (E) small nanophytoplankton, 2-10 $\mu$; (F) large nanophytoplankton 10-20 $\mathrm{m}$. (A-F) Abundance at individual sampling locations (o); average province-wide abundance: Northwest Atlantic Shelves Province ( $\square$ ), Atlantic Artic Province ( $\square$ ), subarctic Boreal Polar Province (BPLR) ( $\square$ ), arctic BPLR ( $\square$ ), others (O); abundance at individual locations in Tracadie Bay, 2002 (A) 
(Fig. 4C). Synechococcus is known and confirmed to be sparse in subpolar and polar waters, but its abundance scales positively with chl a elsewhere (Fig. 4B). Along with picoeukaryotes (Fig. 4A), the heterotrophic bacteria (Fig. 4D), small nanophytoplankton (Fig. 4E) and large nanophytoplankton (Fig. 4F) all scale positively with slopes less than 1 (Table 1).

These patterns extend cytometric macroecology beyond an earlier similar analyses of phytoplankton size classes (Li 2002) and heterotrophic bacteria (Li et al. 2004). They also demonstrate the utility of Longhurst provinces as a coherent level of spatial organization for microbes in the upper ocean. Further, they point towards a macroecology of microbial functional diversity in the ocean.

\section{OUTLIERS}

In delineating the flexibility of nature at work in the ocean (station measurements), and in discerning the regularities (province-wide averages) arising from them, we are reminded of Polkinghorne's (2005) chance and necessity. But what can be said about events that exceed the constraints of natural process where even the inherent flexibility of regular law may not produce the radically different mode of behaviour? These outliers are most interesting because they provoke a search for explanation outside the bounds of normative experience.

In Tracadie Bay, Prince Edward Island, the 2002 summer abundances of microbes in the picoplankton size class were exceedingly high (Figs. 4A,B,D). Small nanophytoplankton, which are slightly larger, were found at concentrations somewhat higher than expected (Fig. 4E), but large nanophytoplankton were much less abundant than expected (Fig. 4F). Cranford et al. $(2006,2008)$ hypothesize that these extraordinary patterns of microbial abundance are an outcome of ecosystem modification. Tracadie Bay is a site of intensive blue mussel Mytilus edulis aquaculture. It is suggested that selective filtration of large particles by mussels creates a refugia for small cells. In such a system, picoplankton encounter at least 2 additional advantages: increased bottom-up capacity from ammonia made available by mussel excretion, and decreased top-down pressure from natural grazers concurrently removed by the mussels. These putative mechanisms offer opportunities for positive feedback, typical of ecosystem disruptive algal blooms (EDAB) noted elsewhere (Sunda et al. 2006). Presumably, in Tracadie Bay, an unusual opportunity is created for animals that can feed on particles in the picoplankton size range but who themselves are not grazed by the mussels.
Macroecology seeks to delineate and understand the natural constraints of organism abundance, distribution and diversity (Brown 1984, 1995, Martiny et al. 2006). For some marine microbial groups, cytometric macroecology already gives a clear picture of natural variability. In at least one case, the bounds were exceeded after the ecosystem was modified. This is also the lesson drawn by Polkinghorne (2005): the unbroken regularity of physical law (e.g. size-selective filtration) coupled with a changing regime (e.g. intense aquaculture) may lead to discontinuous change of behaviour (e.g. picoplankton dominance).

\section{CONCLUSION}

The tributaries of cytometry and macroecology emerged from different wellsprings $25 \mathrm{yr}$ ago. In their inexorable flow towards ocean science, a coalescence of these disciplines provides a framework for pattern recognition at small and large scales. Cytometric macroecology offers an under-explored approach in microbial oceanography. With its holistic perspective, cytometric macroecology emphasizes both the regular ground of possibility (ecological law) and the shuffling operations by which what is potential is made actual (contingency). 'Necessity and chance' is a consilient philosophical construct encompassing both the sciences and the humanities. The construct is a helpful guide towards integrated management of multidimensional global problems, not, as some have claimed, an abdication of human intelligence.

Acknowledgements. I thank all who contributed in different ways to the global dataset, in particular: E. Carmack, O. Ulloa, F. McLaughlin, J. Nelson, S. Zimmermann, J. Eert, B. van Hardenberg, D. Horn, C. Lovejoy, K. Scarcella, G. Alarcon, C. Grob, M. Wood, D. Doolittle, N. Xiuren, C. Yuming, S. Campagna; J. Lemire and the Captain and crew of 'Sedna IV'; the program leaders, managers and scientific participants of the Blue Earth Global Expedition (BEAGLE), and also those of the BIogeochemistry and Optics SOuth Pacific Experiment (BIOSOPE); and staff (Department of Fisheries and Oceans) associated with long term plankton monitoring programs in Bedford Basin and on the Scotian Shelf and the Labrador Sea, especially G. Harrison, E. Head, E. Horne, P. Dickie, K. Pauley, J. Spry, J. Anning, T. Perry, L. Harris, C. Anstey, C. Caverhill and J. Bugden. I express my special thanks to P. Cranford for the work in Tracadie Bay.

\section{LITERATURE CITED}

Azam F, Malfatti F (2007) Microbial structuring of marine ecosystems. Nat Rev Microbiol 5:782-791

Azam F, Fenchel T, Field JG, Gray JS, Meyer-Reil LA, Thingstad F (1983) The ecological role of water-column microbes in the sea. Mar Ecol Prog Ser 10:257-263 
Brown JH (1984) On the relationship between abundance and distribution of species. Am Nat 124:255-279

Brown JH (1995) Macroecology. University of Chicago Press, IL

Brown JH, Maurer BA (1989) Macroecology: The division of food and space among species on continents. Science 243:1145-1150

Brown JH, Gillooly JF, Allen AP, Savage VM, West GB (2004) Toward a metabolic theory of ecology. Ecology 85:1771-1789

Cloern JE, Jassby AD (2008) Complex seasonal patterns of primary producers at the land-sea interface. Ecol Lett 11: 1294-1303

Cranford PJ, Anderson R, Archambault P, Balch T, and others (2006) Indicators and thresholds for use in assessing shellfish aquaculture impacts on fish habitat. Canadian Science Advisory Secretariat, Fisheries and Oceans Canada, Res Doc 2006/034. Available at: www.dfo-mpo.gc.ca/csas/ Csas/Publications/ResDocs-DocRech/2006/2006_034_e.htm

Cranford PJ, Li WKW, Strand O, Strohmeier T (2008) Phytoplankton depletion by mussel aquaculture: high resolution mapping, ecosystem modeling and potential indicators of ecological carrying capacity. International Council for the Exploration of the Seas (ICES) Annual Science Conference 2008, Halifax (Abstract), ICES CM 2008/H:12. Available at: www.ices.dk/iceswork/asc/2008/ThemeSessions/ Theme \%20synopses/2008TS-H-report.pdf

Cullen JJ, Doolittle WF, Levin SA, Li WKW (2007) Pattern and prediction in microbial oceanography. Oceanography (Wash DC) 20:34-46

de Duve C (2007) Thoughts of a senior scientist: Chance and necessity revisited. Cell Mol Life Sci 64:3149-3158

Dubelaar GBJ, Gerritzen PL (2000) CytoBuoy: a step forward towards using flow cytometry in operational oceanography. Sci Mar 64:255-265

Edmonds A (1973) Voyage to the edge of the world. McClelland and Stewart, Toronto

Jacquet S, Prieur L, Avois-Jacquet C, Lennon JF, Vaulot D (2002) Short-timescale variability of picophytoplankton abundance and cellular parameters in surface waters of the Alboran Sea (western Mediterranean). J Plankton Res 24:635-651

Ji R, Davis CS, Chen C, Townsend DW, Mountain DG, Beardsley RC (2007) Influence of ocean freshening on shelf phytoplankton dynamics. Geophys Res Lett 34:L24607. doi:10.1029/2007GL032010

Karl DM, Proctor LM (2007) Foundations of microbial oceanography. Oceanography (Wash DC) 20:16-27

Kerr JT, Kharouba HM, Currie DJ (2007) The macroecological contribution to global change solutions. Science 316: $1581-1584$

Kirchman DL (2008) Microbial ecology of the ocean, 2nd edn. Wiley-Blackwell, Hoboken, NJ

Kühn I, Böhning-Gaese K, Cramer W, Klotz S (2008) Macroecology meets global change research. Glob Ecol Biogeogr $17: 3-4$

Lawton JH (1996) Patterns in ecology. Oikos 75:145-147

Lewis MR, Platt T (1982) Scales of variability in estuarine ecosystems. In: Kennedy VS (ed) Estuarine comparisons. Academic Press, New York

Li WKW (2002) Macroecological patterns of phytoplankton in the northwestern North Atlantic Ocean. Nature 419:154-157

Li WKW (2007) Macroscopic patterns in marine plankton. In: Levin SA (ed) Encyclopedia of biodiversity, p 1-16, Elsevier, Amsterdam

Li WKW (2009) Plankton populations and communities. In: Witman JD, Roy K (eds) Marine macroecology. University of Chicago Press, IL
Li WKW, Harrison WG (2008) Propagation of an atmospheric climate signal to phytoplankton in a small marine basin. Limnol Oceanogr 53:1734-1745

Li WKW, Head EJH, Harrison WG (2004) Macroecological limits of heterotrophic bacterial abundance in the ocean. Deep-Sea Res I 51:1529-1540

Li WKW, Harrison WG, Head EJH (2006) Coherent assembly of phytoplankton communities in diverse temperate ocean ecosystems. Proc R Soc Lond B Biol Sci 273: 1953-1960

> Li WKW, Lewis MR, Harrison WG (2008) Multiscalarity of the nutrient-chlorophyll relationship in coastal phytoplankton. Estuar Coast, doi: 10.1007/s12237-008-9119-7

> Longhurst A (1995) Seasonal cycles of pelagic production and consumption. Prog Oceanogr 36:77-167

Longhurst A (2007) Ecological geography of the sea, 2nd edn. Academic Press, San Diego, CA

> Martiny JBH, Bohannan BJM, Brown JH, Colwell RK and others (2006) Microbial biogeography: putting microorganisms on the map. Nat Rev Microbiol 4:102-112

- Mason AS (2006) Plato on necessity and chaos. Philos Stud 127:283-298

> Maurer BA (2000) Macroecology and consilience. Glob Ecol Biogeogr 9:275-280

> May RM (1995) Necessity and chance: deterministic chaos in ecology and evolution. Bull Am Math Soc 32:291-308

Mills EL (1989) Biological oceanography: an early history, 1870-1960. Cornell University Press, Ithaca, NY

Monod J (1971) Chance and necessity: essay on the natural philosophy of modern biology. Knopf, New York

O'Brien TD, López-Urrutia A, Wiebe PH, Hay S (eds) (2008) ICES Zooplankton Status Report 2006/2007. ICES Cooperative Research Report No. 292, p 168

> Olson RJ, Shalapyonok A, Sosik HM (2003) An automated submersible flow cytometer for analyzing pico- and nanophytoplankton: FlowCytobot. Deep-Sea Res I 50: 301-315

Parsons TR (1965) An automated technique for determining the growth rate of chain-forming phytoplankton. Limnol Oceanogr 10:598-602

Paul JH, Scholin C, van den Engh G, Perry MJ (2007) In situ instrumentation. Oceanography (Wash DC) 20:70-78

Pavé A (2007) Necessity of chance: biological roulettes and biodiversity. C R Biol 330:189-198

Platt T (1985) Structure of the marine ecosystem: its allometric basis. Can Bull Fish Aquat Sci 213:55-64

Polkinghorne JC (2005) Science and providence. Templeton Foundation Press, Philadelphia, PA

Pomeroy LR (1974) The ocean's food web, a changing paradigm. Bioscience 24:499-504

Prosser JI, Bohannan BJM, Curtis TP, Ellis RJ and others (2007) The role of ecological theory in microbial ecology. Nat Rev Microbiol 5:384-392

Redfield AC (1960) The inadequacy of experiment in marine biology. In: Buzzati-Traverso AA (ed) Perspectives in marine biology, p 17-26, University of California Press, Berkeley, CA

Reynolds CS (2002) On the interannual variability in phytoplankton production in freshwaters. In: Williams PJ leB, Thomas DN, Reynolds CS (eds) Phytoplankton productivity: carbon assimilation in marine and freshwater ecosystems. Blackwell, Oxford

Shapiro HM (2003) Practical flow cytometry, 4th edn. WileyLiss, New York

Sheldon RW, Parsons TR (1967) A continuous size spectrum for particulate matter in the sea. J Fish Res Board Canada 24:909-915 
Sheldon RW, Prakash A, Sutcliffe WH Jr (1972) The size distribution of particles in the ocean. Limnol Oceanogr 17:327-340

Smith FA, Lyons SK, Ernest SKM, Brown JH (2008) Macroecology: more than the division of food and space among species on continents. Prog Phys Geogr 32:115-138

Sterner RW, Elser JJ (2002) Ecological stoichiometry: The biology of elements from molecules to the biosphere. Princeton University Press, NJ

Sunda WG, Graneli E, Gobler CJ (2006) Positive feedback and the development and persistence of ecosystem disruptive algal blooms. J Phycol 42:963-974

Swalwell JE, van den Engh G, Armbrust EV (2009) A position sensitive detector for sheathless flow cytometry. American Society of Limnology and Oceanography (ASLO) 2009 Aquatic Sciences Meeting, Nice, France, Abstract ID: 4327

Taylor AH, Allen JI, Clark PA (2002) Extraction of a weak climatic signal by an ecosystem. Nature 416:629-632

Submitted: April 1, 2009; Accepted: May 20, 2009
Thyssen M, Tarran GA, Zubkov MV, Holland RJ, Gregori G, Burkill PH, Denis M (2008) The emergence of automated high-frequency flow cytometry: revealing temporal and spatial phytoplankton variability. J Plankton Res 30: 333-343

Vaulot D, Eikrem W, Viprey M, Moreau H (2008) The diversity of small eukaryotic phytoplankton $(\leq 3 \mu \mathrm{m})$ in marine ecosystems. FEMS Microbiol Rev 32:795-820

Witman JD, Roy K (2009) Marine macroecology. University of Chicago Press, IL

> Yentsch CS, Yentsch CM (2008) Single cell analysis in biological oceanography and its evolutionary implications. J Plankton Res 30:107-117

Yentsch CM, Horan PK, Muirhead K, Dortch Q and others (1983) Flow cytometry and cell sorting: A technique for analysis and sorting of aquatic particles. Limnol Oceanogr 28:1275-1280

Proofs received from author(s): July 23, 2009 